\title{
INSIGHTS INTO BEYOND-LIFE COMPLEX SYSTEMS SUFFERING FROM OBSOLESCENCE
}

\author{
K. R. Lambert ${ }^{1 *}$
}

\section{ARTICLE INFO}

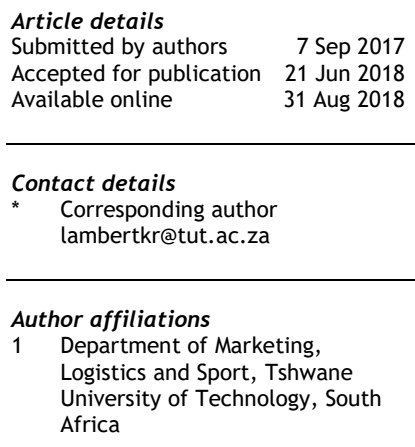

DOI

http://dx.doi.org/10.7166/29-2-1829
ABSTRACT

Supporting and maintaining complex systems in developing countries has numerous challenges, especially in systems that suffer from obsolescence and operate beyond their designed life. Existing methodologies in developing an integrated logistics support system (ILSS) in developed countries are based on resources that are readily available, while in developing countries this is not always the case, and so grounded design rules within a robust framework are required. Various methods and six case studies of high technology systems were used for this paper. Obsolescence effects are considerably wider than the retirement and obsolescence component of present frameworks.

\section{OPSOMMING}

Ondersteuning en instandhouding van komplekse stelsels in ontwikkelende lande het talle uitdagings, veral in stelsels wat verouder en langer as hul ontwerpslewe bedryf word. Bestaande metodologieë vir die ontwikkeling van 'n geïntegreerde logistieke ondersteuningstelsel in ontwikkelde lande berus op hulpbronne wat geredelik beskikbaar is, terwyl dit in ontwikkelende lande nie altyd die geval is nie. Daar word ook grondige ontwerpreëls binne 'n robuuste raamwerk vereis. Gemengde metodes is aangewend en ses gevallestudies van hoëtegnologie stelsels is vir hierdie studie gebruik. Verouderingseffekte is aansienlik wyer as die aftrede- en verouderingskomponent van bestaande raamwerke.

\section{INTRODUCTION}

Supporting and maintaining high technology complex systems in the developing world faces numerous challenges, especially those systems operated beyond designed life and which suffer from obsolescence [1]. In order to gain a competitive advantage, an organization requires different methodologies to attain its business goals and objectives [2]. And to gain and maintain a competitive advantage, the organisation's asset base needs to be managed adequately. This asset base can include high technology complex systems, the support of which can be achieved by implementing a successful ILSS programme. Implementing such a programme can result in a company gaining a competitive advantage, and effectively and efficiently supporting the company's assets [3].

A system can be defined as "a combination of interacting elements organized to achieve one or more stated purposes" [4]. On the other hand, Lambert defines a complex system "... as an integrated system, as it combines numerous different components, parts, line replaceable units (LRUs) and so forth to form an integrated whole or system, used to perform a specific function". [3]. Furthermore, a complex item can be defined as having "... many different failure modes" [5]. By adding more sub-assemblies to a system, the system becomes more functionally complicated, which results in more failure modes, which in turn means more items could fail. Adding the human element of maintenance and operations staff only increases the complexity of the system [3]. The system boundaries change when adding external elements, making it more complicated [6].

Long and extended life cycles can be expected in complex systems, where these life cycles are between 20 and 40 years. The development of the B-52 (the United States Air Force's long-range 
strategic bomber) started in the 1940s, and the aircraft is forecast to be operational until after 2040 [7]. Problems caused by humans result from our "... inability to grasp and manage the increasing complex systems in our world" [8]. Cardullo [9] mentions that "Knowledge varies, over time, from the initial concept of how a basic phenomenon can be applied to the solution of problems to knowledge applied to large complex systems". A high consequence of the failure of complex technology systems is that they need complex support infrastructures in order to maintain and support them throughout their designed or extended life cycle [10].

In the developing world, reality includes using these complex systems beyond their planned life cycle. These 'legacy' or 'beyond life cycle' systems require specifically trained personnel and specialised equipment to support them. Furthermore, high utilisation rates of costly and scarce assets are the standard, and 'long-term over-capacity overload' often happens [5]. In addition, longterm sustainable solutions may falter due to ad hoc replacement/repair decisions [5].

The risks related to obsolescence and diminishing manufacturing sources and material shortages (DMSMS) should be intensively managed so that a company's asset base can be efficiently and effectively controlled. Reducing turnaround times on repairs and reducing long lead times could mitigate such risks. Proper planning for cannibalisation, disposal, modifications, mothballing, phaseout, refurbishment, upgrade, and waste ensures that these obsolescence and DMSMS risks are lowered [3]. Through proactive and adequate inventory management policies, logistics managers can become more effective in servicing their customers' needs [11].

\section{INTEGRATED LOGISTIC SUPPORT SYSTEMS (ILSS)}

Blanchard [12] states that "logistics, which includes the integration of many activities and elements, has become significant in each phase of the system/product life-cycle". Logistics support can be regarded as an economical and effective system support throughout a system's life.

Jones [13, 14] provides two different definitions of logistics - the result of continuous improvement and of the body of knowledge evolving over time. His definitions are as follows:

- "...the applied science of defining supportable systems and of planning and implementing the acquisition and use of resources" [13]; and

- "...the applied science of planning and implementing the acquisition and use of resources" [14].

Jones [13, 14] also provides different definitions of integrated logistics support (ILS). Jones [13] views ILS as a management function that only involves technical disciplines, whereas Jones [14] regards ILS as a management function of all disciplines that develop a support system.

Logistics is the support of all facets of design and development, construction and/or production, evaluation and testing, consumer use, system planning, and retirement. Table 1 below depicts the traditional ILS elements. These logistics support elements should be integrated with all elements of a system.

Table 1: Traditional ILS elements

\begin{tabular}{|l|l|l|}
\hline Maintenance support & Computer resources & Support and test equipment \\
\hline Obsolescence & Manpower and personnel & Configuration management \\
\hline Supply support & Training and training devices & Technical data and documentation \\
\hline Disposal & Facilities & System operational requirements \\
\hline Packaging, handling, storage, transportation & Reliability, availability, maintainability \\
\hline
\end{tabular}

Sources: [12], [13], [14], [15], [16], [17], [18], [19], and [20]

Successful ILS can be achieved by developing and implementing an integrated logistics support plan (ILSP) [21] that will guide management throughout the different life cycle stages [21]. 
The research consisted of three phases. The first phase entailed a literature deconstruction. The second phase dealt with case studies' deconstruction, during which key areas requiring further research were identified. The third and final phase entailed designing a questionnaire, collecting data, and analysis. The findings were assembled and analysed, following which grounded technological rules were proposed.

\section{CAUSES OF OBSOLESCENCE}

Technology today differs from that of 40 years ago. Commercially off the shelf (COTS) component life cycles are between two and three years. The supply life cycle of government contractors is between seven and 15 years, whereas sustainable life cycles are in the range of 25 to 40 years [22]. Obsolescence or DMSMS can be defined as “... the loss or impending loss of manufacturers or suppliers of critical items and raw materials due to discontinuance of production" [23].

Once spare parts are no longer attainable, obsolescence kicks in. This is a result of (for example) the original equipment manufacturer (OEM) going out of business, or the spare part no longer being manufactured. In some cases, the manufacturer might even plan and design for obsolescence so that they can introduce new products to the market. Some items may just be too costly to repair.

Obsolescence affects not only electronic equipment, but also non-electronic components. Obsolescence occurs sooner in electronic than in non-electronic equipment, which might be supportable for years, if not decades [24]. Conflict occurs when systems require life extensions but component obsolescence occurs. In the design of high-cost larger systems, the lifecycle is increasing; but the shortened manufacturing lives of critical components remains an issue.

Obsolescence affects equipment throughout its designed life through to the system's extended life. The system itself is not just affected by obsolescence, but also by the support and test equipment (S\&TE), processes, standards, logistics products, and software [25, cited in 26]. "The risk of having obsolescent components varies from system to system, as the criticality of the function of the component as well as the potential consequence on limiting the operational capability of the system will differ" [1]. Once a component becomes obsolete, it may also make the application, or the nexthigher assembly, obsolete [27].

System support can also become obsolete, such as the necessary skills and knowledge of staff due to retirement, resignation, or dismissal. Turnover of personnel can create a competitive disadvantage for an organisation, as skills and knowledge are lost - particularly if a scarce skill set is difficult to replace.

Obsolescence often affects high technology systems and legacy systems [28]. Organisations are typically reactive to obsolescence issues instead of being proactive [29]. However, the United States (US) Defense MicroElectronics Activity (DMEA) has implemented DMSMS risk management strategies [28]. Organisations must ensure that the technology they implement is not obsolete in the short term [30]. For various reasons, a system might not necessarily be supported by the OEM throughout its life cycle, whether that be its designed life or its extended life [5].

The system life of a high technology complex system is increasing, while the components' life is decreasing, posing a challenge to organisations [31]. This could result in more frequent system upgrades. In the past, when components had longer life cycles, there might be two upgrades in a system's life; but with the shorter life spans of components, a system may need to be upgraded five times or more. The mismatch between a complex system's life cycle and its respective components' life span results in challenges to managing obsolescence, and increases obsolescence costs [32].

\section{LITERATURE DECONSTRUCTION AND FINDINGS OF CASES}

The long life cycles of many complex systems result in obsolescence. Originally a defence industry issue, this now affects other industries, including medical, nuclear, telecommunications, 
petrochemical, railways, and power firms [33]. It is essential to plan for obsolescence, as not planning for it could cause the non-operability of a system. Obsolescence is defined as "...the state when a part is no longer available from the original manufacturing source" [33]. As mentioned previously, DMSMS and obsolescence are synonymous. DMSMS can be defined as "...the loss or impending loss of manufacturers or suppliers of critical items and raw materials due to discontinuance of production" [23]. Therefore, DMSMS and obsolescence can be viewed as the lack of, or non-supply of, repair and spare parts for any reason.

Since the origins of industrial manufacturing, manufacturers have faced obsolescence challenges [27]. Obsolescence can be as a result of product design - so that new sales could occur sooner - or worn-out equipment [17]. Obsolescence can therefore result from poor planning, or it could be intentional [17].

In order for the total cost of ownership (TCO) to decrease, it is suggested that the management of DMSMS be implemented in the contract during the system's life cycle; and "...must be accepted at the highest programmatic levels..." [23]. Typical obsolescence costs include replacing obsolete items and inventory deterioration.

Hutchinson [34] argues that obsolescence costs are "...associated with inventory items that deteriorate while in storage and are not covered by insurance. They can also include losses when the item becomes obsolete through the introduction of a new model or design. Obsolescence costs should be approached with caution and allocated on a per-unit basis".

Different authors ([7], [14], [15], [17], [24], [35], [36], [37], [38]) have given thought to risk management factors or solutions to DMSMS and/or obsolescence. In order to assess the effects of obsolescence, maintenance task analysis (MTA) and the 'logic trouble-shooting diagram' can be used. The former records relevant ILS information, S\&TE data, and replacement of parts [32, 17]. Blanchard [37], in his book Logistics engineering and management proposes a 'maintenance analysis data' section, which provides relevant information about how maintenance factors contribute to obsolescence planning [17]. In many respects, maintenance analysis data [37] and MTA [15] are similar.

Performance-based logistics (PBL) is a method that specifies requirements for operational availability, or the requirements for effectiveness of supply support [15], [14], [1]. One strategy to mitigate obsolescence is PBL [35]. Four principal factors are identified in the DMSMS Guidebook [38] for a successful DMSMS programme: an accurate bill of materials (BOM), commitment by management, predictive tool(s), a team-centred programme, and financial resources. Livingston [7], on the other hand, suggests DMSMS alternatives such as emulation, design modifications, redesign, alternate source, substitution, and life-of-type (LOT) buy. Howard [24] suggests a dual-path (shortand long-term) perspective when pursuing non-electronic obsolescence solutions. The dual-path perspective includes [24]:

1) Overhaul or repair;

2) Reverse engineering;

3) Buying from stock;

4) Manufacturing in accordance with the technical data pack;

5) Form, fit, and function interface;

6) Reclamation; and

7) Redesign.

The American National Standards Institute (ANSI) [36] provides an obsolescence management guide that details a cost-effective obsolescence management process applicable to a product's entire life span. An obsolescence plan is also required for the phase-out and disposal phase [17]. Finkelstein and Guertin [17] can be consulted for the details of an obsolescence plan.

A document that provides system support information is a logistics support plan (LSP). The preliminary LSP serves as input to the LSP, which provides all ILS activities throughout a systems life span ([39], cited in [17]). In later editions of Blanchard [12], [15], no mention is made of an LSP.

Cases from six systems were used to analyse their management of obsolescence - another important 
aspect of an ILSS. Yin [40] argues that "case studies are the preferred strategy when 'how' or 'why questions are being posed, when the investigator has little control over events, and when the focus is on a contemporary phenomenon within some real-life context". Eisenhardt [41] explains the case study research approach as "a research strategy, which focuses on understanding the dynamics present within single settings". Researchers' attention focuses in great depth when using the case study method [42, cited in 43].

Yin [40] mentions that there are different types of case study design: 'single case design' and a 'single unit of analysis' to 'multiple case designs' and 'multiple units of analysis'. For this study, a multiple case design and single unit of analysis was used.

The reliability and validity of the study is justified by using multiple case studies. By using multiple cases, the study is more resilient and the evidence is more credible [44]. The case studies used involved industrial and military high technology complex systems. One of the systems was in the design phase of its life cycle before being shelved. The remaining five systems are older than five years. Two of these suffer from obsolescence, and have been upgraded with newer technology. One system has an obsolescence management plan in place. The remainder of the systems need their obsolescence requirements to be defined. ILS originated in the military (three of the cases are military systems), and has been successfully transferred to industrial systems such as radar, satellite earth stations, a nuclear power plant (modular nuclear reactor), the petrochemical industry, and radio navigational systems. Two of the systems are similar, but operated in different operational environments and in different developing countries. Another two systems are also similar: one is used in an industrial organisation, and the other in a military environment.

Furthermore, from analysis of the case studies, various issues of concern in relation to obsolescence were identified:

1) Shortage of skills at a general level, as well as critical skills;

2) Obsolete or lost specialised skills;

3) Due to the main equipment being upgraded, support and test equipment becomes obsolete or is not supported by the OEM;

4) Obsolete procedures and processes due to continuous improvement initiatives;

5) Electronic component suppliers in South Africa don't consider the market for military-specific components as financially viable, and concentrate more on consumer products. These military specification components need to be sourced from international suppliers - if they even stock the item. Or an industrial specification component must be used, possibly causing more failures.

\section{VERIFICATION OF CONCERN AREAS}

Following from the literature and deconstruction of the cases, a number of concerns were raised that require further exploration. These issues became clear during the data collection phase, using a questionnaire. Respondents were requested to rate the importance of obsolescence determinants: reliability and supplier supportability, new technology, and cost to support. They were also asked to rate specific plans - maintenance plan, obsolescence plan, disposal/system retirement plan, risk management plan, and manpower and personnel (including training) plan) - for improving system performance. A third set of questions asked about obsolescence, where respondents ranked methods of effective obsolescence management (replace complete system, redesign complete or a part of the system, and manage obsolescence under risk).

The study questionnaire was pilot-tested in order to ascertain the appropriate questions for the final study. The questionnaire for the pilot study contained 45 questions in relation to the study, and three questions for additional comments. Twenty-eight respondents received the pilot study questionnaire, and 22 questionnaires returned (a 78.57 per cent response rate). These were analysed, resulting in the final questionnaire.

Two final study questionnaires, with slight differences between them, were used. One questionnaire was used for the military organisation, and the other for the industrial organisations. Two separate questionnaires were used because the military regarded some of the questions as too sensitive. The 
questions in both questionnaires were similar up to question 25. Questions 26 to 34 were only included in the industrial organisations' questionnaire. Three organisational levels were targeted: maintenance, engineering, and management.

A total of 566 respondents in 11 South African organisations received the final questionnaire. The population for the study was 40 organisations that claim to, or do in fact, use ILS. A response rate of 33 per cent was achieved overall, with a 16 per cent response rate from the industrial organisations and a 75 per cent response rate from the military organisation.

A contingency table was used, in which the results were cross-tabulated against two groups of variables: knowledge and experience, and job orientation. For knowledge and experience, the respondents indicated their experience in operating and maintaining systems older than five years, in in operating and maintaining systems less than five years old, and in design. For job orientation, respondents indicated whether they were in the maintenance, engineering, or management field. An independent chi-square test was utilised to ascertain whether enough evidence was available to infer differences between two or more populations. The $p$-values of the chi-square test are provided in Table 2 below.

Table 2: Results of areas of concern vs knowledge and experience and job orientation

\begin{tabular}{||l|l|l||}
\hline \hline \multirow{2}{*}{ Question } & Knowledge and experience & Job orientation \\
\cline { 2 - 3 } & Chi-square (p-value) & Chi-square (p-value) \\
\hline \hline Cost to support & 0.7087 & 0.0123 \\
\hline Disposal/system retirement plan & 0.3452 & 0.2227 \\
\hline Maintenance plan & 0.0793 & 0.3356 \\
\hline Manage obsolescence under risk & 0.4718 & 0.3017 \\
\hline $\begin{array}{l}\text { Manpower \& personnel (including } \\
\text { training) plan }\end{array}$ & 0.7487 & 0.4217 \\
\hline New technology & 0.2237 & 0.4367 \\
\hline Obsolescence plan & 0.2713 & 0.4911 \\
\hline Reliability supportability & 0.1232 & 0.2167 \\
\hline Supplier supt of the & 0.2849 & 0.8118 \\
\hline $\begin{array}{l}\text { Redesign complete or part } \\
\text { system }\end{array}$ & 0.8042 & 0.4154 \\
\hline Replace complete system plan & 0.5976 & 0.3116 \\
\hline Risk management & 0.9532 \\
\hline
\end{tabular}

Source: [3].

There was only one significant result of cost to support and job orientation, providing a p-value of 0.0123 , meaning that these two aspects are dependent as a determinant of obsolescence. There is a weak association between them, as Cramer's V statistic provided a value of 0.1891 . The similarity in the results across knowledge and experience and job orientation reveals that points of view are very similar among the different groups. This might be due to individuals seldom being constrained by a limited job orientation in a developing country: technical staff have management responsibilities, and management staff are often from a technical background.

From the descriptive statistical analysis, the most important source of obsolescence was reduction in reliability, followed by suppliers' ability to offer support and, finally, by cost. The factor that contributed least towards obsolescence was new technology. A weak dependence association is present between the job orientation of the respondents and the obsolescence determinant of cost to support.

Respondents regarded a maintenance plan to be the most important plan, followed by a risk management plan and a personnel (including training) plan. The disposal/system retirement plan and the obsolescence plan were rated as the two least-important plans. Concerns are raised by the low priority given to such plans, as some of the systems used in the study are older than 10 years. Two of the systems suffer from obsolescence. Respondents rated a risk plan as a high priority.

In high technology complex systems, DMSMS can be viewed as “...the point in the system's life cycle 
when spare and repair parts are in short supply or are no longer available, or where a system can no longer be supported for various other reasons" [1]. A system can become non-operational as a result of obsolescence, and therefore obsolescence planning is important. There are many reasons for obsolescence, including advancements in technology, or because components are no longer supplied or manufactured. Not only can the primary system or components become obsolete; so too can organisational processes and procedures, the skills and knowledge of staff, and support and test equipment (S\&TE).

Components that have short life cycles affect the long and/or extended life cycles of high technology systems. This results in more system upgrades, which results in an increase in overall life cycle cost and total cost of ownership. Various authors provide advice to manage obsolescence pro-actively, including maintenance task analysis (MTA) [17], redesign [7], substitution [7], logical troubleshooting diagrams [17], a dual path methodology [24], alternative source determination [26], and performance-based logistics (PBL) [35].

The inclusion of an obsolescence plan as an ILSS element is necessary. The obsolescence plan will address the obsolescence risk; the components susceptible to obsolescence, with timeframes; parts/components/assemblies/sub-assemblies, if systems or equipment are planned for disposal or phase-out; and support systems and skills that might become obsolete. The obsolescence plan must further detail how this will be done. The plan must be linked to other ILS elements in order to support the system during its intended or extended life, and to manage obsolescence pro-actively and successfully.

Following the deconstruction of the literature and the cases, and the corroboration of specific areas of concern, the following grounded technological rules are proposed [3]:

1) Implement an obsolescence programme (including processes and procedures) and document it in a plan;

2) Conduct active risk management with respect to obsolescence, and review it regularly, conducting a regular technology scanning as part of risk review, among other aspects;

3) Manage the obsolescence constraint in order to improve system performance;

4) Ensure that there are multiple suppliers of components, to eliminate 'single supplier' problems;

5) Ensure that reliability and component life cycle data are specific to the operating environment;

6) Attract and retain skilled and knowledgeable staff;

7) Establish excellent client relationships with suppliers; and

8) Ensure accurate obsolescence data and systems.

\section{CONCLUSION}

An obsolescence plan that is effectively developed and implemented, and that forms part of an ILSS, will yield numerous benefits. These include, but are not limited to, decreased total life cycle costs and total cost of ownership, and pro-active risk management of maintenance and system support, instead of reacting to the effects of obsolescence.

\section{REFERENCES}

[1] Marshall, M.M. \& Lambert, K.R. 2008. Insights into supporting complex systems under conditions of obsolescence. Cape Town: PICMET.

[2] Lambert, K.R. 2017. Supporting high-technology systems during periods of extended life cycles by means of integrated logistics support. South African Journal of Industrial Engineering, 28(1), pp. 125-132.

[3] Lambert, K.R. 2008. The development of a framework for an integrated logistics support system within a high technology industry in a developing country. DBL thesis. Pretoria: UNISA..

[4] Haskins, C. (ed.). 2006. Systems engineering handbook: A guide for system life cycle processes and activities. San Diego: INCOSE (International Council on Systems Engineering).

[5] Marshall, M.M. and Lambert, K.R. 2007. Development of an integrated logistic support system (ILSS) in systems beyond designed life. Proceedings of the 2007 International Conference on Industry, Engineering, and Management Systems. pp. 554-563. Cocoa Beach, Florida.

[6] Kasser, J.E. and Palmer, K.D. 2005. Reducing and managing complexity by changing the boundaries of the system. Conference on Systems Engineering Research, Hoboken, NJ, 23-25 March 2005. 
[7] Livingston, H. 2000. [PDF file created 27 November 2000]. GEB1: Diminishing manufacturing sources and material shortages (DMSMS) management practices. [S.l.: s.n.]. Available from: http://www.dmea.osd.mil/docs/geb1_paper.pdf. Accessed: 22 September 2007.

[8] Senge, P.M. 1990. The fifth discipline: The art and practice of the learning organization. New York: Currency and Doubleday.

[9] Cardullo, M.W. 1996. Introduction to managing technology. Somerset: Research Studies Press Ltd.

[10] Lambert, K.R. 2011. Obtaining a competitive advantage by utilizing an integrated logistics support system to enhance the maintenance performance of capital assets. GBATA, Istanbul, July 2011.

[11] Mpwanya, M.F., van Heerden, C.H. \& Lambert, K.R. 2015. Impact of inventory management policies on customers' needs in manufacturing industries' logistics in Gauteng province, South Africa. GBATA, Peniche \& Lisbon, July 2015.

[12] Blanchard, B.S. 1992. Logistics engineering and management. $4^{\text {th }}$ edition. Englewood Cliffs, NJ: PrenticeHall.

[13] Jones, J.V. 1995. Integrated logistics support handbook. $2^{\text {nd }}$ edition. New York: McGraw-Hill.

[14] Jones, J.V. 2006. Integrated logistics support handbook. $3^{\text {rd }}$ edition. New York: SOLE Logistics Press, McGraw-Hill.

[15] Blanchard, B.S. 2004. Logistics engineering and management. $6^{\text {th }}$ edition. New Jersey: Pearson Prentice Hall.

[16] Carpenter, J.L. 1967. Integrated logistics support. Hanover, MD: NASA Center for Aerospace Information (CASI).

[17] Finkelstein, W. and Guertin, J.A.R. 1988. Integrated logistics support: The design engineering link. $1^{\text {st }}$ edition. London: IFS Publications and Springer-Verlag.

[18] Langford, J.W. 1995. Logistics: Principles and applications. New York: McGraw-Hill.

[19] United States (U.S.) Army Regulation 700-127. 1999. Integrated logistics support. Washington, DC: Headquarters, Department of the Army. 10 Nov 1999.

[20] United States (U.S.) MIL-STD-1368-A. 1988. Integrated logistic support program requirements. Washington, DC: Department of Defense.

[21] Lambert, K.R. 2017. Integrated logistics support in high technology complex systems that are utilised beyond their designed life. South African Journal of Industrial Engineering. Awaiting review.

[22] Jane's Business News. 2000. The evolution of COTS in the defence industry [online], 09 October 2000. Available from: http://www.janes.com. Accessed: 20 September 2007.

[23] Tomczykowski, W., Fritz, A. \& Scalia, R. 2000. Program managers handbook: Common practices to mitigate the risk of obsolescence. Maryland: Defense Microelectronics Activity (DMEA).

[24] Howard, M.A. 2002. Component obsolescence: It's not just for electronics anymore. DMSMS 2002 Conference, New Orleans, LA.

[25] Haub, F. 1997. Managing materiel shortages the USN Way. International Defence review - extra. Volume/Issue 002/009, September 1997 (cited in Meyer, Pretorius and Pretorius [26]).

[26] Meyer, A., Pretorius, L. and Pretorius, J.H.C. 2003. A management approach to component obsolescence in the military electronic support environment. SA Journal of Industrial Engineering. 14(2), pp. 121-136.

[27] Boyle, J. 2005. A novel approach to obsolescence management. (n.p.) Defense Electronics. October 2005.

[28] United States (U.S.) Defense MicroElectronics Activity. 2001. Government/ industry microelectronics DMSMS workshop 2001 minutes. Folsom, California.

[29] Burrows, S. 2003. Effective obsolescence management. Unpublished masters dissertation. Bristol: University of Bristol.

[30] Water Environment Federation. 2005. GIS implementation for water and wastewater treatment facilities. [S.l.]: McGraw-Hill Professional.

[31] Pooler, V.H., Pooler, D.J. \& Farney, S.D. 2004. Global purchasing and supply management: Fulfill the vision. [S.l.]: Springer.

[32] Feng, D., Singh, P. \& Sandborn, P. 2007. Lifetime buy optimization to minimize lifecycle cost. Proceedings of the 2007 Aging Aircraft Conference. CALCE, Department of Mechanical Engineering, University of Maryland.

[33] United Kingdom (UK) Ministry of Defence (MoD) Corporate Technical Services. 2004. Ministry of Defence component obsolescence resolution cost metrics study report. UK: QinetiQ and ARINC.

[34] Hutchinson, N.E. 1987. An integrated approach to logistics management. $1^{\text {st }}$ edition. New Jersey: Prentice-Hall.

[35] Acquisition Community Centre (ACC). 2004. Potential obsolescence mitigation strategies [online]. Available from: https://acc. dau.mil/GetAttachment. aspx?id=46257\&pname=file\&lang=en-US\&aid=13743. Accessed: 26 February 2008. Fort Belvoir: Defense Acquisition University.

[36] American National Standards Institute (ANSI). 2007. IEC 62402 ED. 1.0 B Obsolescence management Application guide [online]. Available from: http: //webstore.ansi.org/subscriptions/RecordDetail.aspx?sku=IEC+62402+Ed.+1.0+b\%3A2007. Accessed: 25 February 2008.

[37] Blanchard, B.S. 1983. Logistics engineering and management. [S.l.: s.n.] (cited in Finkelstein and Guertin [17]).

[38] United States (U.S.) Department of Defense (DoD). 2006. Diminishing manufacturing sources and material shortages (DMSMS) guidebook. Washington, DC: Office of the Under Secretary of Defense Acquisition, Technology, \& Logistics, Department of Defense. 
[39] Blanchard, B.S. 1986. Logistics engineering and management. $3^{\text {rd }}$ edition. Englewood Cliffs: Prentice-Hall (cited in Finkelstein and Guertin [17]).

[40] Yin, R.K. 2003. Case study research design and methods. $3^{\text {rd }}$ edition. Thousand Oaks: Sage Publications.

[41] Eisenhardt, K.M. 1989. Building theories from case study research. Academy of Management Review, 14(4), pp. 532-550.

[42] Yan, A. \& Gray, B. 1994. Bargaining power, management control, and performance in United States-China joint ventures: A comparative case study. Academy of Management Journal, 37, pp. 1478-1517 (cited in Lee [43]).

[43] Lee, T.W. 1999. Using qualitative methods in organizational research. Thousand Oaks: Sage Publications.

[44] Herriott, R.E. \& Firestone, W.A. 1983. Multiple qualitative policy research: Optimizing description and generalizability. Educational Researcher, 12, pp. 14-19 (cited in Yin [40]). 